\title{
Ethnobotanical knowledge of the Istro-Romanians of Žejane in Croatia
}

\author{
Andrea Pieroni ${ }^{\mathrm{a}, \mathrm{e}, *}$, Maria Elena Giusti ${ }^{\mathrm{b}}$, Harald Münz ${ }^{\mathrm{c}}$, \\ Cinzia Lenzarini ${ }^{\mathrm{b}}$, Giuliana Turkovićd, Ana Turković ${ }^{\mathrm{d}}$ \\ ${ }^{a}$ Department of Pharmacy, School of Life Sciences, University of Bradford, Richmond Building, \\ Richmond Road, Bradford, West Yorkshire BD7 1DP, UK \\ ${ }^{\mathrm{b}}$ Dipartimento di Storia delle Arti e dello Spettacolo, Università degli Studi di Firenze, \\ Via della Pergola 48, I-50121 Firenze, Italy

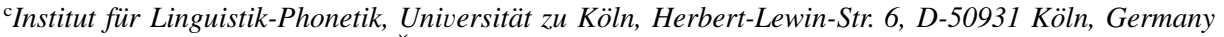 \\ ď̌ejane 90, Mune HR-51212, Croatia \\ ${ }^{\mathrm{e}}$ Department of Social Sciences, Wageningen University and Research Centres, \\ Hollandseweg 1NL-6706 KN Wageningen, The Netherlands
}

Received 7 May 2003; accepted 18 June 2003

\begin{abstract}
An ethno-pharmacognostic survey was carried out in one of the smallest ethnic and linguistic groups in Europe: the Istro-Romanians of the village of Žejane (in Croatia), which has a population of approximately 140 persons, mainly elderly. Using an intensive field participant observation methodology, we recorded about 60 remedies of the local folk pharmacopoeia, and mainly derived from plants. Among them, the uncommon traditions to use homemade vinegar from wild apple (Malus sylvestris) and Cornelian cherries (Cornus mas) for diverse medical purposes, and houseleek (Sempervivum tectorum) against ear pains have been briefly discussed.

(C) 2003 Elsevier Science B.V. All rights reserved.

Keywords: Ethnobotany; Istro-Romanians; Croatia
\end{abstract}

Study area. The area that was investigated in this study is located in the NorthEastern part of the Istrian peninsula (Fig. 1), in Croatia. This inland karstic territory, characterized by numerous dolines, is called in Croatian Čičarija (in Italian Ciceria),

\footnotetext{
*Corresponding author.

E-mail address: a.pieroni@netcologne.de (A. Pieroni).
} 


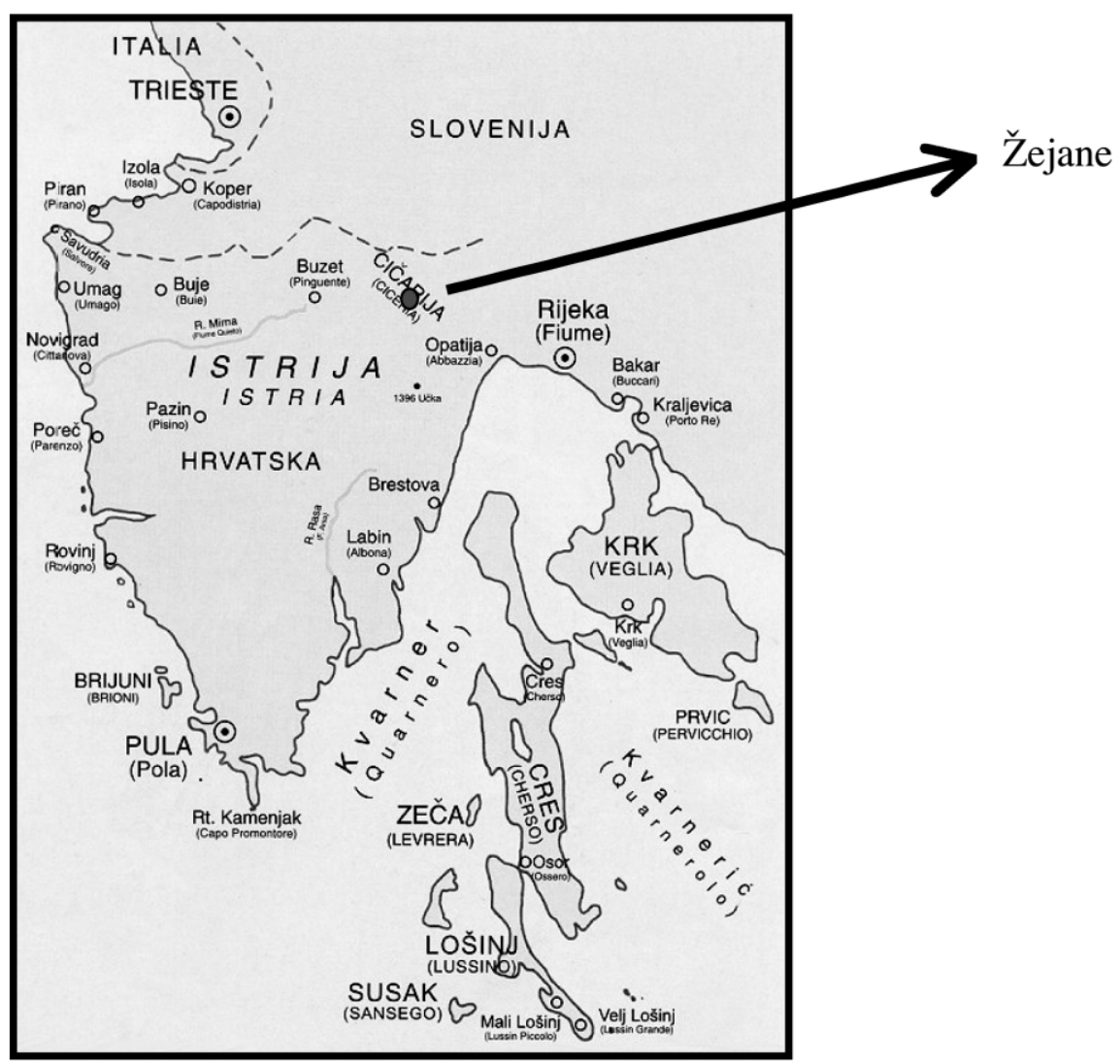

Fig. 1. Location of the studied area.

and presents a typical mountainous and sub-alpine flora. We concentrated our field study in the small village of Žejane (in the local language known as Žejàn), inhabited by one of the smallest ethnic and linguistic group of the world: the IstroRomanians.

Population. The population of Žejane (about 140 inhabitants at present) is IstroRomanian. In the nearby regions they were known during the past as 'Ciribirci' in Croatia, and 'Cicci' in Italy. Their original language belongs to the Romanian group, together with proper Romanian, Macedo-Romanian or Arumanian, and MeglenoRomanian or Meglenitic [1] and is listed in the UNESCO Red Book of Endangered Languages as 'seriously endangered' [2].

Istro-Romanian is classified by linguists in two subgroups: the dialect called locally 'žejànski', and spoken only in Zejane, and the dialect called locally 'vlăški' and spoken in a few centres on the southern side of the Učka Gora mountain 
(Monte Maggiore) located ca. $80 \mathrm{~km}$ south of Žejane: Šušnjevica (Susńevice or Sušńevice in Istro-Romanian), Nova Vas (Noselo or Nosela in Istro-Romanian), Brdo (Bărda in Istro-Romanian), Jesenivik (Sucòdru in Istro-Romanian) and a few other very small villages consisting of no more than 10 households $[3,4]$.

This group probably arrived in Istria around the 14th century (the first records of them date back to 14-15th century [5]) from the Carpathian basin, and were dedicated to pastoral activities. For many years, these Romanian populations have inhabited an area between the Austrian Empire and the Republic of Venice, and became well known in Istria as charcoal burners, coalmen, vinegar producers and traders [6].

Aim of the study. The scope of this field research was to study the use of folkmedical practices among the few remaining people of Źejane.

Previous knowledge on local folk medicine. No ethnobotanical work has been carried out in Istria in the last century. Only a very small folkloric survey was carried out in the 1970s [7], as well as taxonomic-botanical studies [8]. Among the Istro-Romanians, only a phytolinguistic survey on the 'vlåški' dialect has been recently conducted [9], as well as an ethnolinguistic survey on bird and insect names $[10,11]$.

Methodology. The fieldwork was conducted over a period of four weeks in August 2002 , with the last remaining elderly population of the village of Žejane. Only old people, native of the village and still speaking in their daily domestic life as IstroRomanian, were interviewed. Ethnobotanical, ethnopharmaceutical and ethnomedical information were collected using participant observation method and semi-structured interviews [12] with 31 persons (17 women and 14 men, aged between 49 and 82), who still retain traditional knowledge (TK) or remembrances of these practices. Voucher specimens of non-domesticated medicinal plants were identified and stored together with more than $40 \mathrm{~h}$ of tape, photos and audio-video records at the first author's address. Botanical nomenclature follows the standard works of the Italian and Istrian flora $[8,13]$.

Results. Natural ingredients representing the folk pharmacopoeia of the IstroRomanians of Žejane are reported in Table 1 (plants) and Table 2 (animal and other non-locally produced ingredients). In the transcription of the vernacular names of the plants, Istro-Romanian transcription rules were used [4,9]. Frequency of quotation, disappeared uses, and prevalence of female or male expertise for each taxon were recorded as well. 
Table 1

Plant remedies of the folk pharmacopoeias of the Istro-Romanians of Žejane in Croatia

\begin{tabular}{|c|c|c|c|c|c|c|c|c|}
\hline $\begin{array}{l}\text { Botanical taxon } \\
\text { (and voucher } \\
\text { specimen code) }\end{array}$ & $\begin{array}{l}\text { Botanical } \\
\text { family }\end{array}$ & $\begin{array}{l}\text { Istro-Romanian } \\
\text { name }(\mathrm{s}) \text { recorded } \\
\text { in Žejane }\end{array}$ & Status & $\begin{array}{l}\text { Quotation } \\
\text { frequency }\end{array}$ & Part(s) used & Preparation & Administration & Claimed medical use \\
\hline $\begin{array}{l}\text { Abies alba Mill. } \\
\text { (ZEJABI) }\end{array}$ & Pinaceae & ielva & W & * & resin (şmóle $)$ & - & topical application & $\begin{array}{l}\text { antiseptic (also in } \\
\text { veterinary) }\end{array}$ \\
\hline $\begin{array}{l}\text { Achillea } \\
\text { millefolium L. } \\
\quad \text { (ZEJACH) }\end{array}$ & Compositae & odulina & W & क4 & flowering tops & decoction & drunk & anti-obesity and digestive \\
\hline Allium sativum $\mathrm{L}$. & Liliaceae & ai & $\mathrm{C}$ & ap a & bulbs (şcopî) & oleolite & drunk & vermifuge \\
\hline $\begin{array}{l}\text { Artemisia } \\
\quad \text { absinthium L. } \\
\quad \text { (ZEJART1) }\end{array}$ & Compositae & pèlen; pelin & W & की कम क क & aerial parts & decoction & drunk & digestive \\
\hline $\begin{array}{l}\text { Artemisia } \\
\quad \text { vulgaris } \mathrm{L} . \\
\quad \text { (ZEJART2) }\end{array}$ & Compositae & & W & a & aerial parts & decoction & drunk & digestive \\
\hline Beta vulgaris $\mathrm{L}$. & Chenopodiaceae & blitva & $\mathrm{C}$ & 4 क & leaves & - & cooked & depurative \\
\hline $\begin{array}{l}\text { Betula pendula } \\
\text { Roth (ZEJBET) }\end{array}$ & Betulaceae & vrba & $\mathrm{W}$ & top of & young leaves & decoction & drunk & anti-arthritis \\
\hline \multirow[t]{4}{*}{ Brassica oleracea $\mathrm{L}$. } & Cruciferae & capùz & $\mathrm{C}$ & क्ष & leaves & - & $\begin{array}{l}\text { topical application } \\
\text { (back side of the } \\
\text { leaf in contact } \\
\text { with the skin) }\end{array}$ & cicatrising \\
\hline & & & & की कर क क & aerial parts & $\begin{array}{l}\text { liquid remaining } \\
\text { from the } \\
\text { fermentation process } \\
\text { for producing }\end{array}$ & drunk & $\begin{array}{l}\text { to heal haemorrhoids } \\
\text { (taboo: women in } \\
\text { childbirth should avoid } \\
\text { its use otherwise the }\end{array}$ \\
\hline & & & & & & Sauerkraut (verze) & & $\begin{array}{l}\text { baby could get an } \\
\text { intestinal colic) }\end{array}$ \\
\hline & & coruta & & कर कर क क & leaves & - & fodder & $\begin{array}{l}\text { veterinary: nutraceutical } \\
\text { for swine }\end{array}$ \\
\hline $\begin{array}{l}\text { Carum carvi } \mathrm{L} . \\
\text { (ZEJCAR) }\end{array}$ & Umbelliferae & kimel & $\mathrm{W}$ & ats ap as & fruits & $\begin{array}{l}\text { decoction; } \\
\text { macerate in raki }\end{array}$ & drunk & digestive \\
\hline $\begin{array}{l}\text { Centaurium } \\
\text { erytrhaea } \text { Rafn. } \\
\text { (ZEJCEN) }\end{array}$ & Gentianaceae & tåvžântróže & $\mathrm{W}$ & \& & aerial parts & decoction & drunk & digestive \\
\hline Chelidonium & Papaveraceae & snoìnita & W & \& & latex & - & topical application & anti-warts \\
\hline
\end{tabular}




\begin{tabular}{|c|c|c|c|c|c|c|c|c|}
\hline $\begin{array}{l}\text { Botanical taxon } \\
\text { (and voucher } \\
\text { specimen code) }\end{array}$ & $\begin{array}{l}\text { Botanical } \\
\text { family }\end{array}$ & $\begin{array}{l}\text { Istro-Romanian } \\
\text { name(s) recorded } \\
\text { in Žejane }\end{array}$ & Status & $\begin{array}{l}\text { Quotation } \\
\text { frequency }\end{array}$ & Part(s) used & Preparation & Administration & Claimed medical use \\
\hline \multicolumn{9}{|l|}{$\begin{array}{l}\text { majus } \mathrm{L} . \\
\quad \text { (ZEJCHE) }\end{array}$} \\
\hline \multirow[t]{2}{*}{$\begin{array}{l}\text { Cornus mas L. } \\
\text { (ZEJCOR) }\end{array}$} & Cornaceae & corn & W & top of top* & fruits & $\begin{array}{l}\text { fermented to produce } \\
\text { vinegar (otet) }\end{array}$ & see Malus sylvestris & see Malus sylvestris \\
\hline & & & & \& & fruits & syrup & drunk & nutraceutical \\
\hline Cucurbita pepo L. & Cucurbitaceae & tìcve & $\mathrm{C}$ & A A क क & fruits & - & fodder & $\begin{array}{l}\text { veterinary: nutraceutical } \\
\text { for swine }\end{array}$ \\
\hline Euphorbia sp. & Euphorbiaceae & iårba de şerpe & W & Aक & latex & - & topical application & anti-warts \\
\hline $\begin{array}{l}\text { Fragaria vesca } \mathrm{L} \text {. } \\
\text { (ZEJFRA) }\end{array}$ & Rosaceae & fråžica & W & $*$ & fruits & - & consumed & nutraceutical \\
\hline $\begin{array}{l}\text { Juniperus communis } \\
\text { (ZEJJUN) }\end{array}$ & Cupressaceae & smríca & W & \&* & galbules (briń) & distilled oil & external application & anti-rheumatic \\
\hline \multirow[t]{5}{*}{$\begin{array}{l}\text { Malus sylvestris } \\
\text { MILL. (ZEJMAL) }\end{array}$} & Rosaceae & lisnic & W & \& \$ & fruits & $\begin{array}{l}\text { fermented to produce } \\
\text { vinegar (otet) }\end{array}$ & drunk & anti-obesity \\
\hline & & & & top of top* & & & $\begin{array}{l}\text { heated and topically } \\
\text { applied }\end{array}$ & $\begin{array}{l}\text { anti-bruises (also in } \\
\text { veterinary) }\end{array}$ \\
\hline & & & & toptot & & & $\begin{array}{l}\text { heated and topically } \\
\text { applied by a cloth } \\
\text { on feet or hands }\end{array}$ & anti-fever \\
\hline & & & & \&o do* & & & topically applied & to heal headache \\
\hline & & & & to at & & & fodder & $\begin{array}{l}\text { veterinary: nutraceutical } \\
\text { for swine }\end{array}$ \\
\hline $\begin{array}{l}\text { Matricaria recutita } \mathrm{L} \text {. } \\
\text { (ZEJMAT) }\end{array}$ & Compositae & camomila & $\mathrm{W}$ & \& \& & flowering tops & decoction & drunk & $\begin{array}{l}\text { digestive; } \\
\text { tranquilliser; } \\
\text { vermifuge (children) }\end{array}$ \\
\hline $\begin{array}{l}\text { Medicago sativa } \mathrm{L} \text {. } \\
\text { (ZEJMED) }\end{array}$ & Leguminosae & iårba spågña & W & क \& & aerial parts & - & fodder & $\begin{array}{l}\text { veterinary: nutraceutical } \\
\text { for rabbits }\end{array}$ \\
\hline $\begin{array}{l}\text { Plantago lanceolata } \mathrm{L} \text {. } \\
\text { (ZEJPLA) }\end{array}$ & Plantaginaceae & bucvița & $\mathrm{W}$ & ads & leaves & - & topical application & cicatrising \\
\hline Prunus domestica L. & Rosaceae & česspa; sliva & $\mathrm{C}$ & क क & fruits & distillate & topical application & cicatrising \\
\hline $\begin{array}{l}\text { Rosa canina } \mathrm{L} . \\
\text { (ZEJROS) }\end{array}$ & Rosaceae & şípâc & W & a a & pseudofruits & decoction & drunk & depurative \\
\hline $\begin{array}{c}\text { Rubus idaeus L. } \\
\text { (ZEJRUB1) }\end{array}$ & Rosaceae & målinița & W & कo & fruits & - & consumed & nutraceutical \\
\hline
\end{tabular}




\begin{tabular}{|c|c|c|c|c|c|c|c|c|}
\hline $\begin{array}{l}\text { Botanical taxon } \\
\text { (and voucher } \\
\text { specimen code) }\end{array}$ & $\begin{array}{l}\text { Botanical } \\
\text { family }\end{array}$ & $\begin{array}{l}\text { Istro-Romanian } \\
\text { name }(s) \text { recorded } \\
\text { in Žejane }\end{array}$ & Status & $\begin{array}{l}\text { Quotation } \\
\text { frequency }\end{array}$ & Part(s) used & Preparation & Administration & Claimed medical use \\
\hline & & & & a & & syrup & drunk & nutraceutical \\
\hline \multirow[t]{2}{*}{$\begin{array}{l}\text { Rubus ulmifolius } \\
\text { SCHOTT. } \\
\text { (ZEJRUB2) }\end{array}$} & Rosaceae & mùrgvâ & $\mathrm{W}$ & ato to to & fruits & - & consumed & nutraceutical \\
\hline & & & & \& & & syrup & drunk & nutraceutical \\
\hline $\begin{array}{l}\text { Rumex acetosella } \\
\text { L. (ZEJRUM) }\end{array}$ & Polygonaceae & kiselita & W & Af af & $\begin{array}{l}\text { whole aerial parts } \\
\text { with seeds }\end{array}$ & dried & $\begin{array}{l}\text { fodder, mixed with } \\
\text { wheat bran }\end{array}$ & $\begin{array}{l}\text { veterinary: anti-diarrhoeic } \\
\text { for cattle }\end{array}$ \\
\hline Sambucus nigra $\mathrm{L}$. & Caprifoliaceae & bsga & $\mathrm{W}$ & क क क & $\begin{array}{l}\text { fruits } \\
\text { flower }\end{array}$ & $\begin{array}{l}\text { decoction } \\
\text { syrup }\end{array}$ & $\begin{array}{l}\text { drunk } \\
\text { drunk }\end{array}$ & $\begin{array}{l}\text { anti-fever } \\
\text { nutraceutical }\end{array}$ \\
\hline Secale cereale $\mathrm{L}$. & Graminae & secåra & $\mathrm{C}$ & toptop* & $\begin{array}{l}\text { seeds } \rightarrow \text { flour } \\
(\text { faríre de secåra) }\end{array}$ & $\begin{array}{l}\text { cooked with water } \\
\text { and potatoes }\end{array}$ & consumed & roborant \\
\hline Sempervivum tectorum L: (ZEJSEM) & Crassulaceae & pičór de galíre & $\mathrm{W}$ & \& & leaf juice & - & instilled in the ear & to heal pains of the ears \\
\hline Solanum tuberosum L. & Solanaceae & cumpìr & $\mathrm{C}$ & 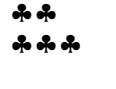 & tubers & $\begin{array}{l}\text { cut in slices } \\
\text { cooked with rye } \\
\text { flour and water }\end{array}$ & $\begin{array}{l}\text { topical application } \\
\text { consumed }\end{array}$ & $\begin{array}{l}\text { anti-headache } \\
\text { roborant }\end{array}$ \\
\hline $\begin{array}{l}\text { Taraxacum officinale } \\
\text { Weber (ZEJTAR) }\end{array}$ & Compositae & $\begin{array}{l}\text { divlia radice; } \\
\text { maslačac }\end{array}$ & $\mathrm{W}$ & Aक a & flowers & $\begin{array}{l}\text { 'honey' (obtained } \\
\text { cooking the flowers } \\
\text { with sugar) }\end{array}$ & consumed & antitussive \\
\hline $\begin{array}{l}\text { Tilia cordata } \\
\text { MILL. (ZEJTIL) }\end{array}$ & Tiliaceae & lìpa & $\mathrm{W}$ & atpos & $\begin{array}{l}\text { whorls } \\
\text { flowers }\end{array}$ & $\begin{array}{l}- \\
\text { decoction }\end{array}$ & $\begin{array}{l}\text { consumed } \\
\text { drunk }\end{array}$ & $\begin{array}{l}\text { nutraceutical } \\
\text { non specified }\end{array}$ \\
\hline Trifolium sp. pl. & Leguminosae & trefoi; ditel'à & $\mathrm{W}$ & Ap as & aerial parts & - & fodder & $\begin{array}{l}\text { veterinary: nutraceutical } \\
\text { for rabbits, cattle, swine }\end{array}$ \\
\hline Triticum aestivum $\mathrm{L}$. & Graminae & grâv & $\mathrm{C}$ & Af of & $\begin{array}{l}\text { seeds } \rightarrow \text { flour } \\
\text { (faríre de } \\
\text { fârmenta) }\end{array}$ & $\begin{array}{l}\text { food preparation } \\
\text { made by cooking } \\
\text { together flour, } \\
\text { butter, butter, sugar, } \\
\text { eggs and water }\end{array}$ & consumed & galactagogue \\
\hline & & & $\mathrm{C}$ & \& & seeds $\rightarrow$ flour & $\begin{array}{l}\text { food preparation } \\
\text { made by boiling } \\
\text { wheat flour } \\
\text { and milk }\end{array}$ & consumed & roborant (children) \\
\hline $\begin{array}{l}\text { Urtica dioica } \mathrm{L} . \\
\text { (ZEJURT) }\end{array}$ & Urticaceae & $\begin{array}{l}\text { copriva; } \\
\text { urzica }\end{array}$ & W & \& & leaves & boiled & consumed & nutraceutical \\
\hline
\end{tabular}




\begin{tabular}{|c|c|c|c|c|c|c|c|c|}
\hline $\begin{array}{l}\text { Botanical taxon } \\
\text { (and voucher } \\
\text { specimen code) }\end{array}$ & $\begin{array}{l}\text { Botanical } \\
\text { family }\end{array}$ & $\begin{array}{l}\text { Istro-Romanian } \\
\text { name(s) recorded } \\
\text { in Žejane }\end{array}$ & Status & $\begin{array}{l}\text { Quotation } \\
\text { frequency }\end{array}$ & Part(s) used & Preparation & Administration & Claimed medical use \\
\hline $\begin{array}{l}\text { Vaccinium myrtillus L. } \\
\text { (ZEJVAC) }\end{array}$ & Ericaceae & iåvorica & $\mathrm{W}$ & of of & fruits & - & food & nutraceutical \\
\hline $\begin{array}{l}\text { Viscum album } \mathrm{L} \text {. } \\
\text { (ZEJVIS) }\end{array}$ & Loranthaceae & bisk & $\mathrm{W}$ & ** & $\begin{array}{l}\text { aerial parts } \\
\text { before } \\
\text { fructification }\end{array}$ & $\begin{array}{l}\text { macerate in raki } \\
\text { with honey }\end{array}$ & drunk & digestive \\
\hline Zea mais $\mathrm{L}$. & Graminae & gris & $\mathrm{C}$ & Ap ap as & $\begin{array}{l}\text { seeds } \rightarrow \text { flour } \\
\text { (faríre de griz) }\end{array}$ & $\begin{array}{l}\text { cooked with } \\
\text { water and potatoes }\end{array}$ & consumed & roborant \\
\hline
\end{tabular}

Quotation frequency: quoted by less than $10 \%$ of the informants; $\$$ : quoted by more than $10 \%$ and less than $40 \%$ of the informants; a o a : quoted by more than $40 \%$ of the

informants; *. dis 
Table 2

Animal, mineral, and other remedies used in folk medical practices among the Istro-Romanians of Žejane in Croatia

\begin{tabular}{|c|c|c|c|c|}
\hline Ingredient & Quotation frequency & Preparation & Administration & Claimed medical use \\
\hline black ribbon & \& क a & - & knot on the skin & anti-warts \\
\hline cattle faeces & \&* & - & topical application & to heal burns \\
\hline coal & 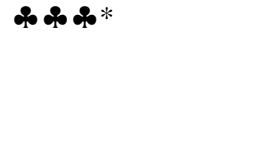 & $\begin{array}{l}\text { putting water on hot coal, and } \\
\text { playing a special formula } \\
\text { (while making three time } \\
\text { the Holy Cross) }\end{array}$ & washes & against the evil eye (uróki) \\
\hline grape distillate (raki) & \& की & - & topical application & cicatrising \\
\hline grape vinegar $($ otetet) & क & - & see Malus sylvestris & see Malus sylvestris \\
\hline milk cream & \& & - & topically applied & to heal psoriasis \\
\hline ritual & 96 \% & - & $\begin{array}{l}\text { one has to ask the ill person: } \\
\text { 'What are you doing?'; } \\
\text { he/she has to answer: } \\
\text { 'I cut barley', and simulating } \\
\text { this action; all that has to be } \\
\text { repeated for three times }\end{array}$ & $\begin{array}{l}\text { to heal sty (orz, same } \\
\text { name used for barley) }\end{array}$ \\
\hline salt & \& क & mixed with water and straw & fodder & $\begin{array}{l}\text { veterinary: roborant } \\
\text { for cattle }\end{array}$ \\
\hline \multirow[t]{2}{*}{ snake skin } & \&* & $\begin{array}{l}\text { roasted on the pot, then an } \\
\text { infusion is prepared }\end{array}$ & drunk & against high fever \\
\hline & \&* & - & consumed & to heal lunge diseases \\
\hline soil & \&* & - & leg kept into the soil & against viper bite in the leg \\
\hline sugar & \& & $\begin{array}{l}\text { heated in a pot (sometimes with a } \\
\text { few drops of olive oil), often } \\
\text { adding milk }\end{array}$ & consumed/drunk & antitussive \\
\hline wine & 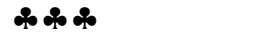 & boiled wine with bread and sugar & consumed & galactagogue \\
\hline
\end{tabular}

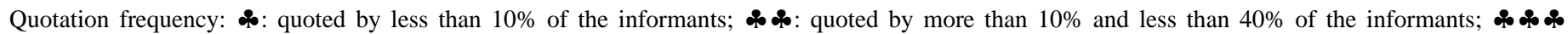
quoted by more than $40 \%$ of the informants; *: disappeared use. 
Conclusions. The folk pharmacopoeia of the Istro-Romanians of Žejane present elements of diverse origin: uses, which are very common in the Austro-German area (caraway, Carum carvi; sauerkraut, fermented Brassica oleracea; wormwood, Artemisia absinthium; silver fir, Abies alba; juniper, Juniperus communis) [14], others maybe also learnt and acquired from the Croatians and even which have been widely documented in the past in a broad Central European area [15] (wormwood, dandelion flowers, Taraxacum officinale; elderberry flowers, Sambucus nigra), and others coming from the Venetian coastal area (grape distillate, wine).

Nevertheless, we also recorded uses that seem to suggest the permanence of a few signs of a possible original Romanian folk pharmacopoeia. The most interesting of these recorded practices regards Sempervivum tectorum (houseleek), used among the Istro-Romanians against ear pains, and the a few medicinal uses of homemade vinegar.

A similar use of $S$. tectorum was recorded in Tuscany [16]; recently, polyphenols from this species have shown antimicrobial activity [17], while the antioxidant [18] and liver protecting activity of its extracts [19,20] have been previously demonstrated.

Vinegar was traditionally produced in Žejane from wild apples (Malus sylvestris) and Cornelian cherries (Cornus mas). Informants told us that only later in the 20th century they began to buy grape vinegar from the Italo-Venetians along the Istrian coasts (vines were never cultivated in Cičarija) and continue in this other way their very old tradition of transporting it to the markets of Trieste and Vienna. The use of vinegar, whose homemade production is frequently mentioned in the Romanian folklore [21], is used in the studied area internally as anti-obesity product, and externally against bruises, fever and headache. This phenomenon should be further investigated in order to understand also the difference in the phytochemistry between grape vinegar and wild apples and Cornelian cherries vinegar. Folk medical practices are represented in Žejane in a mainly female domain, as field studies in other Mediterranean areas [22] have also pointed out: men's expertise is generally circumscribed to veterinary practices, and only rarely, as in case of distillates, play a role in the traditional knowledge related to the domestic cosmos.

\section{Acknowledgments}

Special thanks are due to all the people of Žejane, and especially to Draga and Franjo Turković, Davorka Stambolić; Maria Kukarić, Maria Stankovic, Mario Stankovich, Ana Marmilić, Drago and Josip (Pepo) Doričić; to Cassandra Quave and Prof. María de los Reyes Gonzáles-Tejero (University of Granada, Spain), for their help in improving a previous version of the manuscript; to Prof. Dr. Wolfgang Dahmen and Nadia Hense (Institute for Romanian Languages and Literature, University of Jena, Germany), for their bibliographic and kind support in building the first contacts with the last Istro-Romanians of Žejane; to Prof. Goran Filipi (University of Pula/Pola, Croatia), for the precious bibliographic suggestions; to Tullio Vorano (Museum of Labin/Albona) for all the logistic assistance offered. A special thanks to the Land North Rhine-Westphalia (Germany) for the financial 
support to H. Münz, who received the Bennigsen Price 2001 for young scientists and artists.

\section{References}

[1] Grimes BF, editor. Ethnologue-CD ROM. Dallas, USA: Summer Institute of Linguistics, 2000.

[2] Salminen P. UNESCO Red Book Report on Endangered Languages: Europe. Available at: www.helsinki.fi/ tasalmin/europe_report.html, last visited 16th October 2003.

[3] Filipi G. Istrorumänisch. In: Okuka M, editor. Wieser Enziklopädie des europäischen Ostens. Band 10, Klagenfurt, Austria: Wieser Verlag, 2002. p. 91.

[4] Kovačec A. Istrorumunjsko-hrvatski Rječnik. Pula, Croatia: Znantstvena udruga Mediteran, 1998.

[5] Dahmen W. Das Istrorumänisch. In: Holtus G, Radtke E, editors. Rumänistik in der Disksussion. Tübingen, Germany: Gunter Narr Verlag, 1986. p. 242.

[6] Curtis E. La Lingua, la Storia, le Tradizioni degli Istroromeni. In: L'Istrorumeno. La Lingua la Cultura, la Storia. Trieste, Italy: Associazione di Amicizia Italo-Romena Decebal, 1992. p. 6-13.

[7] Radole G. Medicina Popolare Istriana. Trieste, Italy: Libreria Internazionale Italo Svevo, 1971.

[8] Pericin C. Fiori e piante dell'Istria distribuiti per l'ambiente. Rovinj, Croatia: Centro Ricerche Storiche, 2001.

[9] Pericin C. Atti Centro Ricerche Storiche Rovigno 1999;XXIX:627.

[10] Filipi G. Entomonimi nell'istrorumeno moderno. In: Fusco F, Orioles V, Parmeggiani A, editors. Processi di Convergenza e Differenziazione nelle Lingue dell'Europa Medioevale e Moderna. Atti del Convegno Internazionale, Udine, 9-11 Dicembre 1999. Udine, Italy: Centro Internazionale sul Plurilinguismo, 2000.

[11] Filipi G. Annales-Anali Koprskega Primorja in Bližnjih Pokrajin/Annali del Litorale Capodistriano e delle Regioni Vicine 1995;6:77-88.

[12] Russel Bernard H. Research Methods in Anthropology. Qualitative and Quantitative Approach. Walnut Creek, USA: Altamira Press, 2002.

[13] Pignatti S. Flora d'Italia. Bologna, Italy: Edizioni Edagricole, 1997.

[14] Höfler M. Volksmedizinische Botanik der Germanen. Berlin, Germany: VWB, 1990. (Reprint Edition 1908).

[15] Bächtold-Stäubli H, Hoffmann-Krayer E, editors. Handwörterbuch des deutschen Aberglaubens. Berlin, Germany: Walter de Gruyter, 1987. (Reprint Edition 1930).

[16] Uncini Manganelli RE, Tomei PE. Documenti per la Conoscenza delle Tradizioni EtnoFarmacobotaniche in Toscana. Lucca, Italy: Edizioni S. Marco Litotipo, 1999.

[17] Abram V, Donko M. J Agr Food Chem 1999;47:485.

[18] Blazovics A, Pronai L, Feher J, Kery A, Petri G. Phytother Res 1993;7:95.

[19] Blazovics A, Feher J, Feher J, Kery A, Petri G. Phytother Res 1993;7:98.

[20] Blazovics A, Gonzalez-Cabello R, Barta I, Gergely P, Feher J, Kery A, Petri G. Phytother Res 1994;8:33.

[21] Mihalcu M, Maier RO. Anuarul Insitutului de Etnografie si Folclor Constantin Brailoiu 1994;4:5.

[22] Pieroni A. Wild food plants and Arbëresh women in Lucania, Southern Italy. In: Howard P, editor. Women and plants. Case studies on gender relations in biodiversity management and conservation. London, UK: Zed Press, 2003. p. 66-82. 